\title{
Factors Influencing Bacterial Diversity in the Rhizosphere of Cucumbers and Tomatoes in the Arabian Peninsula
}

\author{
Elham A. Kazerooni and Abdullah M. Al-Sadi* \\ Department of Plant Sciences, College of Agricultural and Marine Sciences, Sultan Qaboos University, PO Box 34, Al-Khod \\ 123, Oman \\ "For correspondence: alsadi@squ.edu.om; alsadiam@gmail.com
}

Received 21 October 2020; Accepted 12 March 2021; Published 16 April 2021

\begin{abstract}
The Arabian Peninsula is characterized by generally hot and dry conditions. Although limited studies addressed bacterial diversity in this part of the world, there is a lack of information about bacterial diversity under farming systems. This study investigated bacterial diversity across three farms in Oman, at the South Eastern part of the Arabian Peninsula. Pyrosequencing was used to analyze bacterial communities from the rhizosphere soil of tomatoes and cucumbers grown in the farms. Results revealed that bacterial diversity is variable among various farms. Chao 1 richness and Shannon diversity estimates demonstrated that soils from the three farms differed in the levels of bacterial diversity. Proteobacteria was the major phylum in the soil samples from all farms. Gammaproteobacteria was the main and most abundant class in the rhizosphere soil of cucumber, while Gammaproteobacteria, Alphaproteobacteria, Deltaproteobacteria, Bacilli, Actinobacteria, Cytophagia and Nitrospira were common in the rhizosphere soil of tomatoes. The genera Bacillus, Nitrospira, Sphingomonas, Gemmatimonas and Pseudomonas were the most common in the rhizosphere of both crops in the three farms. Principle component analyses showed that bacterial diversity in the rhizosphere of cucumbers and tomatoes was found to be affected by the farming system but not the crop type. The study also presents information about the most common bacterial groups under farming systems in the Arabian Peninsula. Most of the bacterial taxa were saprophytic, suggesting that they play a role in cucumber and tomato growth and disease prevention. (C) 2021 Friends Science Publishers
\end{abstract}

Keywords: NGS; Pyrosequencing; Desert; Soil; Bacteria; Oman

\section{Introduction}

Soil microbial communities are essential indicators of soil health and their biodiversity influences ecosystem functioning (Xu et al. 2018; Nunan et al. 2020; Raza et al. 2020). Soil bacteria play crucial roles in biogeochemical cycles and nutrient turnover in terrestrial ecosystems (Gans et al. 2005; Krishna and Mohan 2017; Lehtovirta-Morley 2018). Changes in soil environment, water content, soil type, $\mathrm{pH}$ and plant diversity influence soil microbial composition, diversity and interaction with plants (Wu et al. 2008). Agricultural land use is defined as one of the most significant factors that alter soil physiochemical properties and biological processes (Jangid et al. 2008; Jesus et al. 2009).

Historically, it has been hypothesized that application of soil cattle manure, organic or inorganic fertilizers alters soil microbial structure, diversity and soil health. On the other hand, repeated application of fertilizers may cause environmental hazards. Soupir et al. (2006) proposed that frequent application of manure may introduce fecal microbes into the soil flora which have the potential to pose environmental hazards by changing the endogenous microbial community.

Although a number of studies have demonstrated that shifts in land use can cause major changes in microbial communities, our understanding of how land use along with plant and soil properties may have impact on the abundance and presence of specific taxonomic groups is still unclear and the relationship is complex (Lauber et al. 2008).

Developments in sequencing technologies have allowed us to study the community structure of microbial communities (Bao et al. 2019; Eichmeier et al. 2019). Historical reports proved that only $0.1-1 \%$ of bacterial communities could be detected based on cultivation methods and will not give us true reflection of bacterial community and diversity (Sandaa et al. 2001; Smit et al. 2001). Nowadays, 16S rRNA sequencing has been applied in many studies, not only to examine bacterial community composition but also to understand to what extent changes in bacterial community composition gets influenced by external factors (Qin et al. 2018; Wang et al. 2018). 
Oman is a dry country located at the South Eastern part of the Arabian Peninsula. Date palm is the most important fruit crop in the country, with a total production of 368,000 tons annually (FAO 2019). Tomato is the top vegetable crop in terms of production $(199,000$ tons annually). Other important crops include mangoes, acid limes, bananas and cucumbers. Most farms in Oman are in the coastal areas and they follow a conventional system in which they rely on growing different crops in the same farm. They also rely extensively on the use of pesticides and inorganic fertilizers. There are very few organic farms in the country. There are also some farms in desert areas where temperatures can reach $50^{\circ} \mathrm{C}$ in summer. Desert farms follow a conventional system, but environmental conditions determine the crops which can be grown in deserts.

We hypothesized that soil bacterial composition varies among locations or different crops. Using 454 pyrosequencing techniques, we examined bacterial diversity in the rhizosphere of cucumbers and tomatoes. This manuscript provides detailed information and statistical assessment of the soil bacterial communities at the class and genus level and their possible connection with soil properties, plant species and farming practices.

\section{Materials and Methods}

\section{Sample collection and experimental design}

The experiments focused on cucumber and tomato grown in three farms. A detailed description of the farms is shown in Table 1. Collection of soil samples was done during December-January (2013-2014), and randomized samples were taken from the rhizosphere of cucumber and tomato grown in the three farms.

Soil (1 kg) was collected from the rhizosphere of each crop. Sampling was carried out from five randomly selected plants in each farm. Soil samples were taken from three sections around the active feeder roots $(<1 \mathrm{~cm})$. Sterile plastic containers were used to preserve soil samples. Each soil sample was thoroughly homogenized and passed through sieve to remove stone and plant debris. Part of each soil sample was ground using liquid nitrogen and then preserved at $-80^{\circ} \mathrm{C}$ prior to DNA extraction. The rest of the soil samples were kept at $10^{\circ} \mathrm{C}$ for further soil physiochemical tests.

\section{Determination of soil physicochemical properties}

Soil samples were ground and sieved (2 mm sieve). Physicochemical properties of soil samples examined as described by Al-Ghaithi et al. (2016). Soil textural classification (Gee and Bauder 1986), electrical conductivity (EC) and $\mathrm{pH}$ measurements (Zhang et al. 2005), potassium (K), phosphorus, total inorganic and organic carbon, nitrogen, sulphate $\left(\mathrm{SO}_{4}\right)$ and organic matter were determined (Al-Ghaithi et al. 2016). Three replicates were used for each sample.

\section{DNA extraction for PCR amplification}

Total DNA was extracted from $0.05 \mathrm{~g}$ soil samples as described by the modified protocol of Volossiouk et al. (1995) as described by Kazeeroni and Al-Sadi (2016).

\section{Pyrosequencing and bioinformatic analyses}

The universal primer set $28 \mathrm{~F}$ and $519 \mathrm{R}$ were used for the amplification of 16S rRNA bacterial gene (Liu et al. 2007). The amplified samples were submitted for high throughput 454-pyrosequencing to the Research and Testing Laboratory (RTL, Lubbock, TX, USA) (Dowd et al. 2008a).

The pyrosequencing raw data were edited to reduce the effect of sequencing error. RDP v. 9 was used to check high quality sequences (Cole et al. 2009). Sequences which were less than $300 \mathrm{bp}$ or with low quality ends and tags were removed from the data set. Sequences were checked for chimers using UCHIME chimera detection software (Edgar et al. 2011). The selected sequences were compared with high quality sequences obtained from NCBI and filtered at $97 \%$ similarity. Finally, outputs were validated based on taxonomic distance methods (Dowd et al. 2005; Dowd et al. 2008a, b. Further analysis of pyrosequencing data was conducted as explained by Kazeeroni and Al-Sadi (2016). Richness and Shannon diversity estimates and weighted UniFrac, unweighted UniFrac and Bray-Curtis analyses were carried out as explained by Al-Balushi et al. (2017).

\section{Statistical analysis}

Differences among soils in their physicochemical characteristics were analyzed using Tukeys' Studentized Range test (SAS, SAS Institute Inc., USA) at $P<0.05$.

\section{Results}

\section{Soil physiochemical characteristics}

Soils obtained from farms differed in their physicochemical properties (Table 1). All soil types were loamy sand. The $\mathrm{pH}$ range was from 7.7 to 8.4, while the EC (salinity) ranged from 0.9 to $7.72 \mathrm{mS}$. The highest level of salinity was observed in DE and the lowest level was observed in OR (P $\leq 0.05$; Table 1). Total inorganic carbon (TIC), total organic carbon (TOC), nitrogen $(\mathrm{N})$, phosphorus $(\mathrm{P})$, potassium $(\mathrm{K})$ and sulphate $\left(\mathrm{SO}_{4}\right)$ were different among the different farms (Table 1).

Bacterial richness, diversity and composition in the rhizosphere of cucumber

Differences were found between the three farms, designated $\mathrm{OR}, \mathrm{TR}$ and $\mathrm{DE}$, in the level of bacterial diversity. Cucumber grown in OR farm harbored a higher level of 
Bacterial Diversity in the Rhizosphere of Tomatoes and Cucumbers / Intl J Agric Biol, Vol 25, No 5, 2021

Table 1: Physicochemical analysis of soil samples

\begin{tabular}{|c|c|c|c|c|c|c|c|c|c|c|c|}
\hline Sample code & Farm\# & $\mathrm{pH}$ & $\mathrm{EC}(\mathrm{mS})$ & $\% \mathrm{C}(\mathrm{TC})$ & $\%$ TIC & $\% \mathrm{TOC}$ & $\% \mathrm{~N}$ & $\mathrm{P}(\mathrm{mg} / \mathrm{kg})$ & $\mathrm{K}(\mathrm{mg} / \mathrm{kg})$ & $\mathrm{SO}_{4}(\mathrm{mg} / \mathrm{kg})$ & $\%$ organic matter \\
\hline ORCU & 1 & $8.4 \mathrm{a}$ & $0.988 \mathrm{~d}$ & $2.957 \mathrm{c}$ & $1.059 \mathrm{~b}$ & $1.898 \mathrm{a}$ & $0.059 \mathrm{~b}$ & $3.706 \mathrm{a}$ & $7.460 \mathrm{c}$ & $23.928 \mathrm{de}$ & $60.900 \mathrm{a}$ \\
\hline ORTO & 1 & $8.4 \mathrm{a}$ & $1.211 \mathrm{~d}$ & $2.905 \mathrm{c}$ & $0.015 \mathrm{c}$ & $2.900 \mathrm{a}$ & $0.050 \mathrm{~b}$ & $3.246 \mathrm{a}$ & $24.575 \mathrm{~b}$ & $33.499 \mathrm{~d}$ & $60.362 \mathrm{a}$ \\
\hline TRCU & 2 & $7.7 \mathrm{c}$ & $4.980 \mathrm{~b}$ & $7.952 \mathrm{~b}$ & $5.651 \mathrm{a}$ & $2.301 \mathrm{~b}$ & $0.015 \mathrm{c}$ & $4.480 \mathrm{a}$ & $58.365 \mathrm{a}$ & $76.570 \mathrm{c}$ & $60.726 \mathrm{a}$ \\
\hline DECU & 3 & $8.0 \mathrm{~b}$ & $6.240 \mathrm{a}$ & $8.036 \mathrm{~b}$ & $5.181 \mathrm{a}$ & $2.855 \mathrm{a}$ & $0.259 \mathrm{a}$ & $0.095 \mathrm{~b}$ & $51.783 \mathrm{a}$ & $124.426 \mathrm{~b}$ & $60.472 \mathrm{a}$ \\
\hline DETO & 3 & $7.8 \mathrm{c}$ & $7.720 \mathrm{a}$ & $6.900 \mathrm{~b}$ & $4.132 \mathrm{a}$ & $2.768 \mathrm{a}$ & $0.020 \mathrm{c}$ & $3.272 \mathrm{a}$ & $45.639 \mathrm{a}$ & $193.817 \mathrm{a}$ & $60.804 \mathrm{a}$ \\
\hline
\end{tabular}

Codes starting with the letters OR, TR and DE designate to different farms, while CU denotes for cucumber and TO denotes for tomato.

Abbreviations denote to: $\mathrm{EC}=$ electrical conductivity, $\mathrm{TIC}=$ total inorganic carbon, $\mathrm{TOC}=$ total organic carbon, $\mathrm{N}=$ nitrogen, $\mathrm{P}=$ phosphorus, $\mathrm{SO}=$ sulphate and $\mathrm{K}=$ potassium

Values with the same letter in the same column are not significantly different from each other at $P<0.05$ (Tukey's Studentized Range test, S.A.S.)

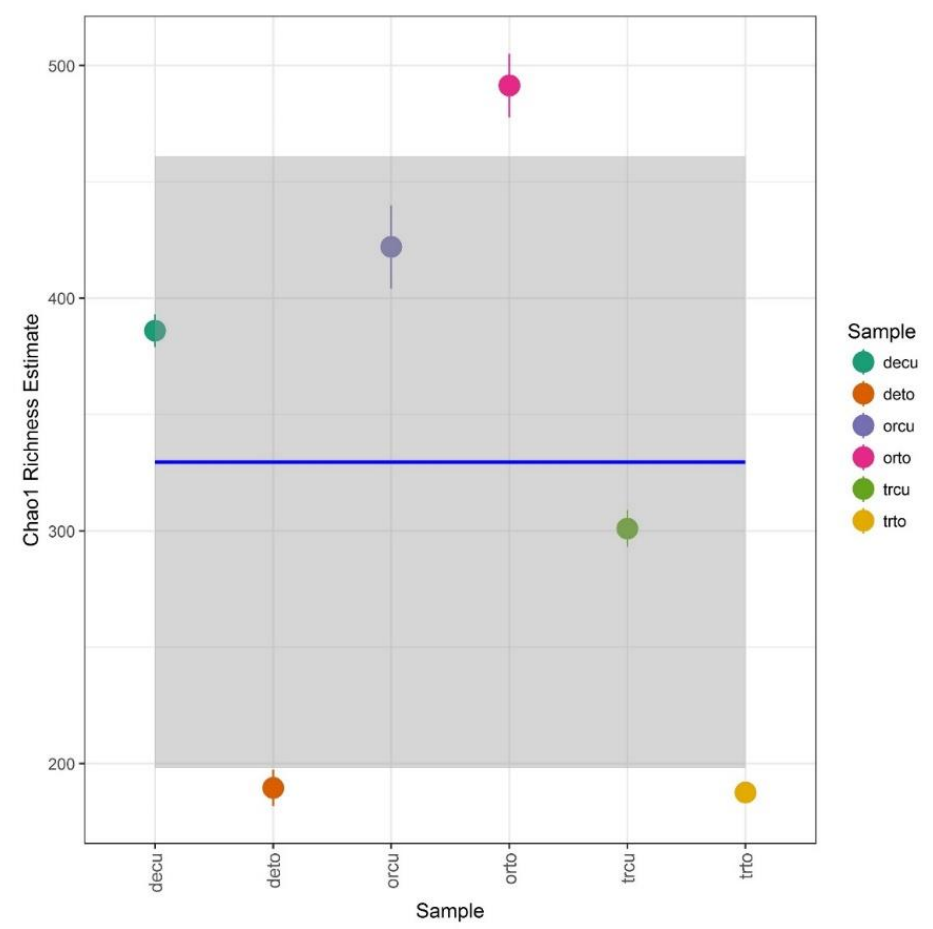

Fig: 1: Chao1 richness within the total microbiome data of soil samples obtained from the rhizosphere of cucumber and tomato grown in three farms. Sample codes are described in Table 1

bacterial diversity compared to TR and DE. The Chaol richness values were 422 for cucumber soil from OR (ORCU) compared to 386 and 301 for soil from DE (DECU) and TR (TRCU) farms, respectively (Fig. 1). Similarly, Shannon diversity was highest in OR (Fig. 2).

Proteobacteria dominated phyla in soil samples from OR, DE and TR farms. Other common phyla included Acidobacteria, Actinobacteria, Firmicutes and Bacteriodetes (Fig. 3). Gammaproteobacteria was the main and most abundant class in cucumber grown in OR, DE and TR (Fig. 4). Some classes such as Alphaproteobacteria, Betaproteobacteria, Deltaproteobacteria, Clostridia, Actinobacteria, Nitrospira, Planctomycetia, Acidobacteriia, Actinobacteria, and Bacilli were present in the three farms (Fig. 4). Fluctuation in class distribution was observed under different farms. Several bacterial genera were detected in all farming systems. Bacillus, Nitrospira, Sphingomonas, Gemmatimonas, and Pseudomonas were shared between the three farms (Fig. 5).

\section{Bacterial richness, diversity and composition in the rhizosphere of tomato}

Bacterial diversity was higher in the rhizosphere of tomatoes grown in OR compared to TR and DE. The Chao1 richness values were 491, 189 and 187 for tomatoes grown in soil from the ORTO, DETO and TRTO in soils from the two other farms (Fig. 1). Shannon diversity was highest for ORTO (5.6) compared to DETO (4.4) and TRTO (4.3) (Fig. 2).

Pyrosequencing showed that the majority of bacterial taxa in the three farms belong to the Proteobacteria and Firmicutes phyla (Fig. 3). The other dominant phyla included Actinobacteria, Acidobacteria, Cyanobacteria and Bacteroidetes (Fig. 3). Our results detected 46 classes in OR compared to 27 classes in TR and 35 in DE. The most common classes in these farming systems were Gammaproteobacteria, Alphaproteobacteria, Deltaproteobacteria, Actinobacteria, Nitrospira, 


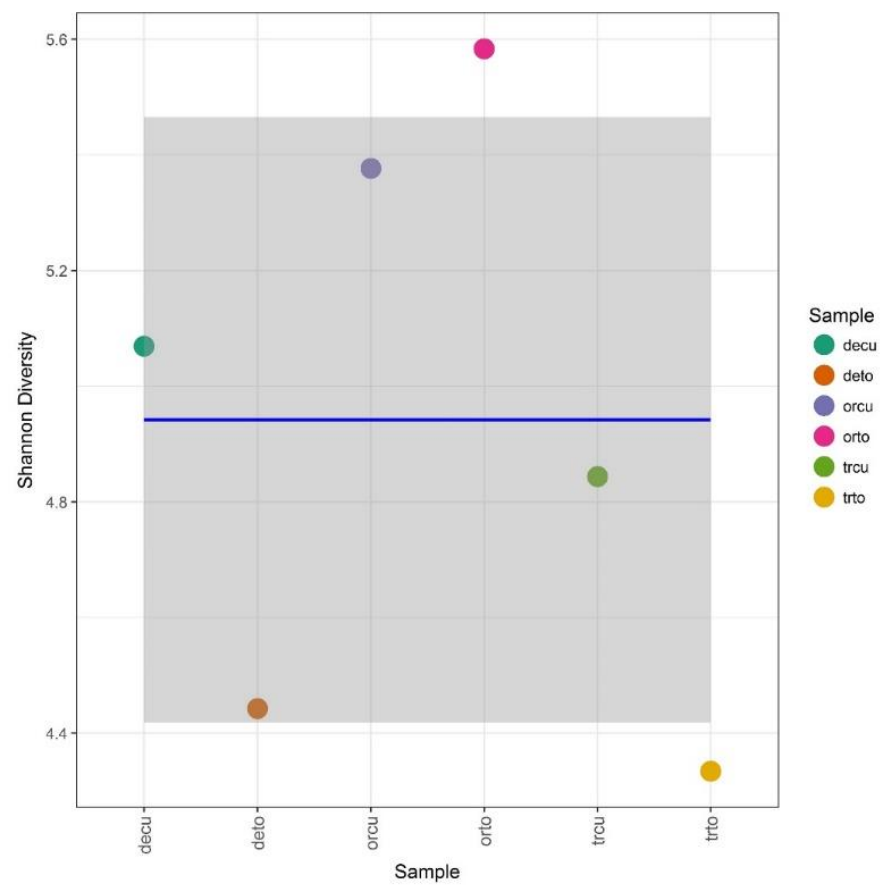

Fig. 2: Shannon diversity within the total microbiome data of soil samples obtained from the rhizosphere of cucumber and tomato

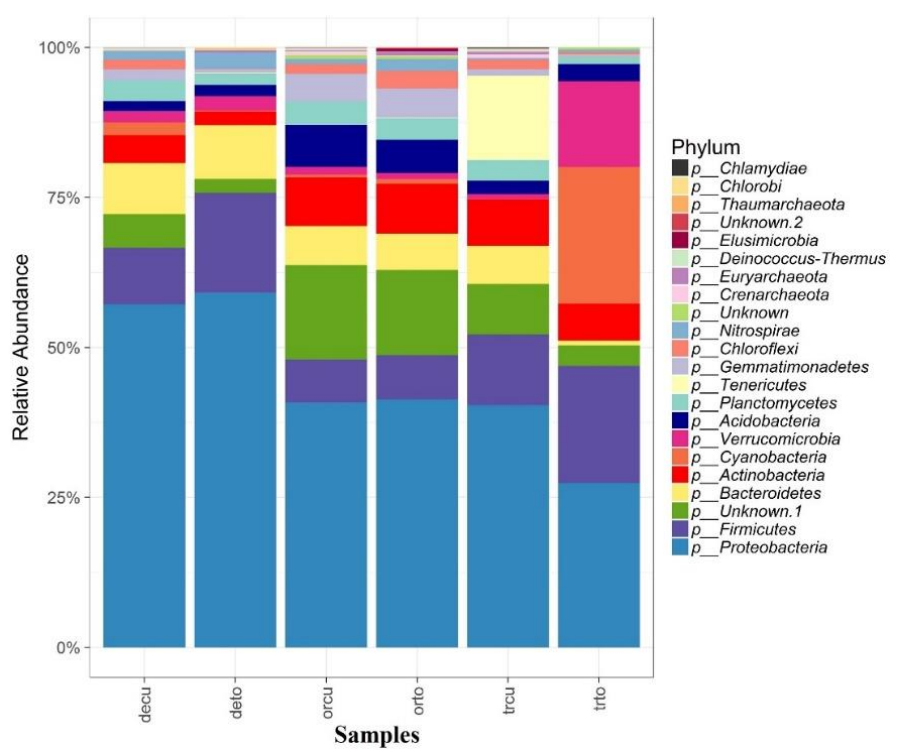

Fig: 3: Phylum-level relative abundance of bacterial communities in the rhizosphere of cucumber and tomato

Planctomycetia, Sphingobacteriia, and Acidobacteriia (Fig. 4). Some classes such as Flavobacteriia and Anaerolineae were not detected in TR (Fig. 4). Genera recovered from all farms included Bacillus, Nitrospira, Sphingomonas, Gemmatimonas and Pseudomonas (Fig. 5).

\section{Relationship between bacterial diversity and farming systems}

Separation of soil samples from different farming systems was depicted by using Bray-Curtis analysis, weighted UniFrac and unweighted UniFrac distances (Fig. 6). The analysis clearly separated samples from the OR farm from other samples. However, the there was no clustering based on host crop.

\section{Discussion}

Our findings showed that bacterial community and diversity were high under the extreme dry conditions of Oman. 


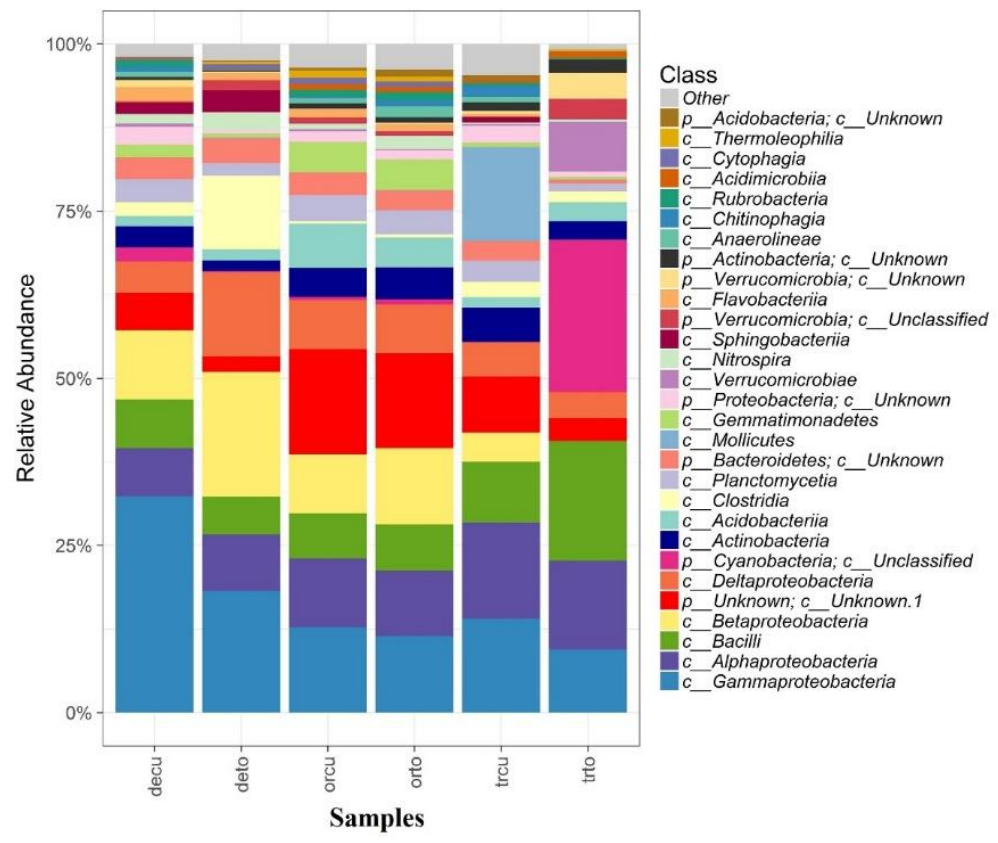

Fig. 4: Class-level relative abundance of bacterial communities in the rhizosphere of cucumber and tomato

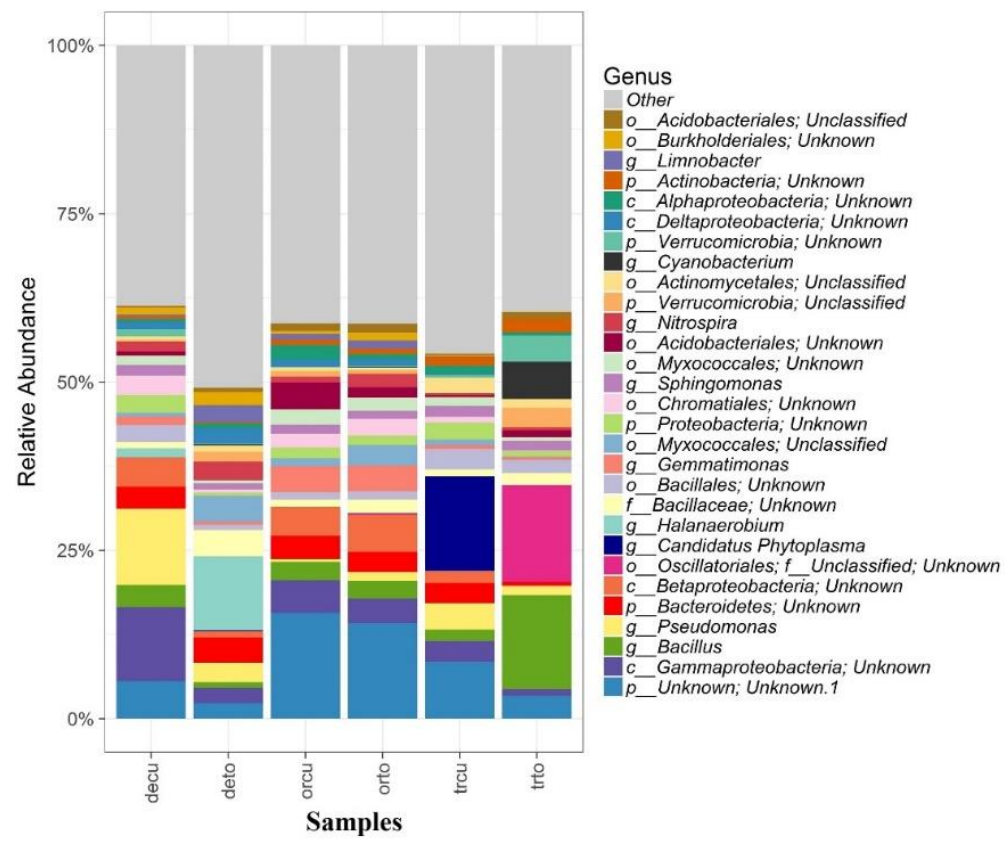

Fig. 5: Genus-level relative abundance of bacterial communities in the rhizosphere of cucumber and tomato

In the first part of this study, we evaluated bacterial community present in the rhizosphere of cucumber grown in OR, TR and DE farms. In this investigation, Proteobacteria was the most dominant phylum in OR, TR and DE farms growing cucumber. There was fluctuation in the presence of classes in OR, TR and DE growing cucumber. Alphaproteobacteria was abundant in TRCU while more Betaproteobacteria and Gammaproteobacteria were detected in DECU. Moreover, a higher percentage of
Deltaproteobacteria was observed in ORCU. To interpret these results, the concept of oligotrophic and copiotrophic has been used by researchers (Meyer 1994; Fierer et al. 2007). A group of bacteria which predominate in soils with high nutrient availability are defined as fast growing or copiotrophic bacteria while slow growing or oligotrophic bacteria are defined as a group of bacteria that flourish in soils with low amount of nutrients. In our study we found higher levels of Betaproteobacteria in DE, followed by OR 
and then TR. Total $\mathrm{N}$ was higher in ORCU compared to TRCU while DECU possesses higher $\mathrm{N}$ compared to ORCU. The higher abundance of Betaproteobacteria in OR compared to TR could be due to the higher amount of $\mathrm{N}$. Moreover, the higher abundance of Betaproteobacteria in DE compared to OR and TR might be related to the high level of total $\mathrm{C}$ and total $\mathrm{N}$. The percentage of the other common phyla such as Acidobacteria and Actinobacteria was higher in ORCU compared to TRCU and DECU. The highest percentage of Bacteriodetes and Firmicutes was observed in DECU and TRCU, respectively.

In the other part of this research, we investigated bacterial composition in the rhizosphere of tomato grown in OR, TR and DE farms. Proteobacteria was the most dominant phyla present in OR, TR and DE grown tomato. Betaproteobacteria class was dominant in DETO. Betaproteobacteria are considered as copiotrophic bacteria and it is expected to have their population to be in lower level in organic farms (Diepeningen et al. 2006; Fierer et al. 2007). Total $\mathrm{N}$ was higher in DETO compared to TRTO and ORTO and the lowest amount of $\mathrm{N}$ was observed in TRTO. The higher abundance of Betaproteobacteria in OR compared to TR could be due to the higher amount of $\mathrm{N}$ and $\mathrm{pH}$. On the other hand, we observed a higher population of Actinobacteria in OR and this observation was consistent with a study by Grantina et al. (2011). The reason could be due to the presence of recalcitrant carbon sources. Fließbach et al. (2007) mentioned organic soils as rich sources of recalcitrant carbon. It has been reported that Actinobacteria are capable of decomposing recalcitrant carbon sources and play a role in carbon cycling and organic matter turnover (Acosta-Martínez et al. 2008; Jenkins et al. 2009). It would be expected to have higher diversity of Actinobacteria in organic fields than conventional fields. Moreover, our findings are consistent with other studies that indicated significant increase in Actinobacteria population with higher $\mathrm{pH}$ values (Jones et al. 2009; Nacke et al. 2011).

The effect of soil edaphic factors on the formation of microbial communities has been addressed by several studies (Yang et al. 2017; Jin et al. 2019; Bickel and Or 2020). He et al. (2012) indicated nitrogen, $\mathrm{pH}$ and soil organic carbon as the most important factors that have influence on soil microbial function and composition. Previous reports noted that besides total nitrogen, $\mathrm{pH}, \mathrm{EC}$ and organic matter, specific plant groups such as legumes and forb can be considered as important factors affecting soil microbial composition (Li et al. 2014; Qu et al. 2016).

Long term $\mathrm{N}$ fertilization can have a positive impact on Gammaproteobacteria and a negative impact on Deltaproteobacteria (Zhang et al. 2014; Zhou et al. 2017). Our finding followed the same trend for cucumber farms but not for tomato farms. In cucumber farms, the highest percentage of Gammaproteobacteria and the lowest percentage of Deltaproteobacteria were detected in DECU which had the highest amount of nitrogen $(\mathrm{N}: 0.2 \%)$. In tomato farms, the highest percentage of
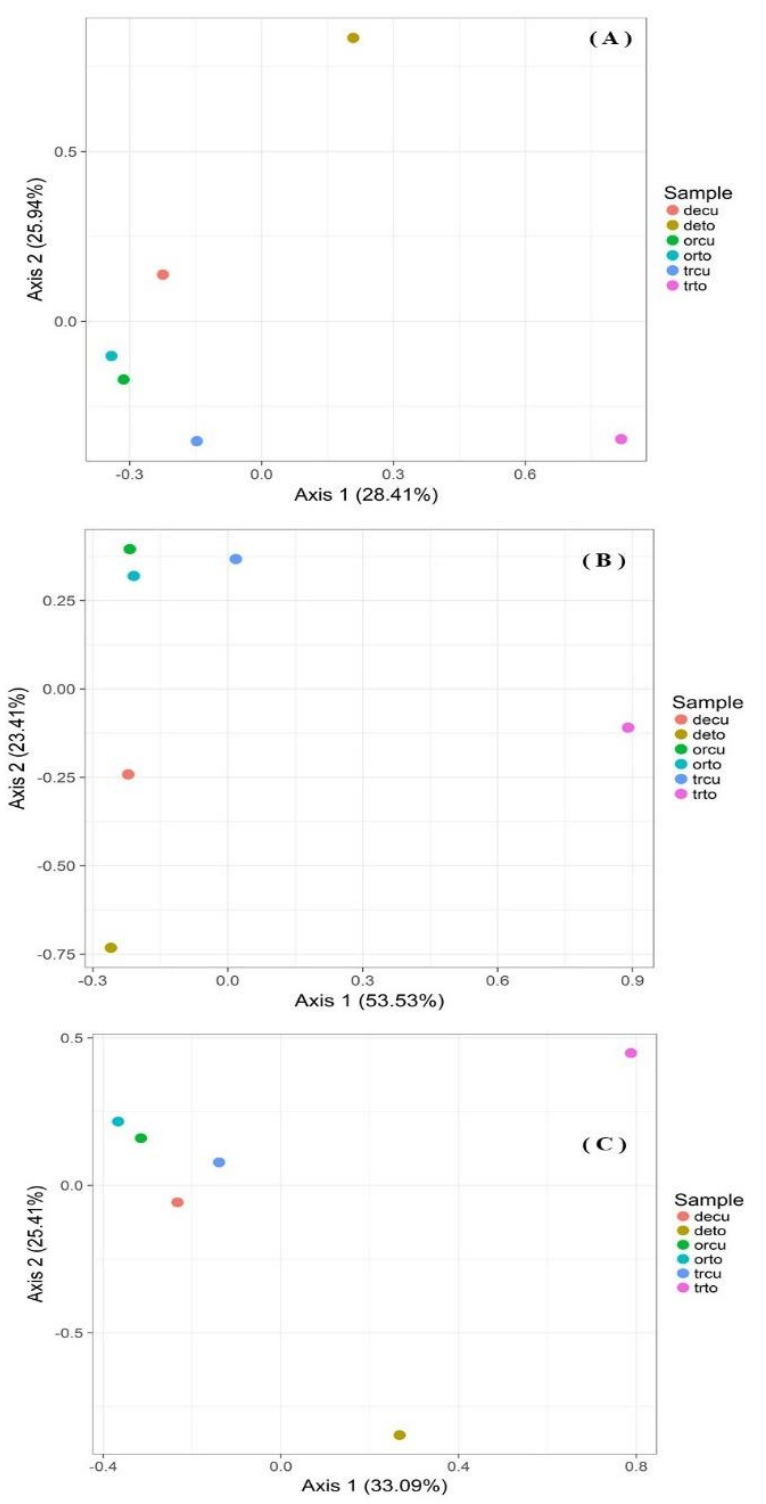

Fig. 6: Principal component analysis of the relative abundances of bacterial communities in in the rhizosphere of cucumber and tomato based on Bray-Curtis analysis (A), weighted UniFrac distances (B) and unweighted UniFrac distances (C). The rhizosphere soils samples were from cucumber and tomato

Gammaproteobacteria and Deltaproteobacteria was observed in DETO (N: 0.02\%). Some studies reported the negative impact of nitrogen addition on reduction of recalcitrant carbon decomposition (Craine et al. 2007) and this may affect Actinobacteria which play a role in the carbon cycling (Ventura et al. 2007). Pan et al. (2014) indicated the presence of correlation between Actinobacteria, Acidobacteria, Verrucomicrobia and K, AL, and Ni. In our study the highest percentage of K (58.3\%) was detected in TR (TRCU) and in this farm the population of Actinobacteria was high.

Previous studies reported soil $\mathrm{pH}$ as a primary factor 
that has an influence on the richness and diversity of bacteria (Cline and Zak 2015; Ling et al. 2016; Xue et al. 2017). It indicated that the highest richness and diversity were observed when the $\mathrm{pH}$ was near the neutral or alkaline levels (Rousk et al. 2009; Ramirez et al. 2010). Our findings agree with this, as generally bacterial diversity was higher in soils with higher $\mathrm{pH}$ values.

\section{Conclusion}

Our findings suggest that farming systems in the Arabian Peninsula have a relatively high level of bacterial diversity. This bacterial abundance and composition may lead to a change in soil quality and fertility. Different types of farming systems can support various groups of beneficial bacteria and this is crucial for improving soil quality and fertility. Further investigation is required to evaluate the impact of farming systems on the abidance of beneficial and pathogenic bacteria in the long run.

\section{Acknowledgments}

Thanks to growers for facilitating sample collection. We acknowledge financial support from SQU (IG/AGR/CROP/16/03), (EG/AGR/CROP/16/01) and VALE Oman.

\section{Author Contributions}

E.A. Kazerooni: planned work; conducted experiments, analyzed data and wrote the manuscript; A.M. Al-Sadi: planned work; supervised work, analyzed data, and proof read the manuscript.

\section{Conflict of Interest}

The authors declare that they have no known conflict of interest.

\section{Data Availability}

All data related to this work are presented in the manuscript.

\section{Ethics Approval}

Not applicable.

\section{References}

Acosta-Martínez V, S Dowd, Y Sun, V Allen (2008). Tag-encoded pyrosequencing analysis of bacterial diversity in a single soil type as affected by management and land use. Soil Biol Biochem 40:2762-2770

Al-Balushi I, M Bani-Uraba, N Guizani, M Al-Khusaibi, AM Al-Sadi (2017). Illumina MiSeq sequencing analysis of fungal diversity in stored dates. BMC Microbiol 17; Article 72
Al-Ghaithi AG, MA Hanif, WM Al-Busaidi, AM Al-Sadi (2016). Increased sodium and fluctuations in minerals in acid limes expressing witches' broom symptoms. SpringerPlus 5; Article 418

Bao L, W Cai, X Zhang, J Liu, H Chen, Y Wei, X Jia, Z Bai (2019). Distinct microbial community of phyllosphere associated with five tropical plants on Yongxing island, south China sea. Microorganisms 7; Article 525

Bickel S, D Or (2020). Soil bacterial diversity mediated by microscale aqueous-phase processes across biomes. Nat Commun 11; Article 116

Cline LC, DR Zak (2015). Soil microbial communities are shaped by plantdriven changes in resource availability during secondary succession. Ecology 96:3374-3385

Cole JR, Q Wang, E Cardenas, J Fish, B Chai, RJ Farris, AS Kulam-SyedMohideen, DM McGarrell, T Marsh, GM Garrity, JM Tiedje (2009). The Ribosomal Database Project: Improved alignments and new tools for rRNA analysis. Nucl Acids Res 37:141-145

Craine JM, C Morrow, N Fierer (2007). Microbial nitrogen limitation increases decomposition. Ecology 88:2105-2113

Diepeningen ADV, OJD Vos, GW Korthals, AHCV Bruggen (2006). Effects of organic versus conventional management on chemical and biological parameters in agricultural soils. Appl Soil Ecol $31: 120-135$

Dowd SE, TR Callaway, RD Wolcott, Y Sun, T McKeehan, RG Hagevoort, TS Edrington (2008a). Evaluation of the bacterial diversity in the feces of cattle using 16S rDNA bacterial tag-encoded FLX amplicon pyrosequencing (bTEFAP). BMC Microbiol 8; Article 125

Dowd SE, Y Sun, RD Wolcott, A Domingo, JA Carroll (2008b). Bacterial tag encoded FLX amplicon pyrosequencing (bTEFAP) for microbiome studies: Bacterial diversity in the ileum of newly weaned Salmonella-infected pigs. Foodborne Pathog Dis 5:459-472

Dowd SE, J Zaragoza, JR Rodriguez, MJ Oliver, PR Payton (2005). Windows.NET network distributed basic local alignment search toolkit (W.ND-BLAST). BMC Bioinform 6; Article 93

Edgar RC, BJ Haas, JC Clemente, C Quince, R Knight (2011). UCHIME improves sensitivity and speed of chimera detection. Oxf J Bioinform 27:2194-2200

Eichmeier A, T Kiss, T Necas, E Penazova, D Tekielska, M Bohunicka, L Valentova, R Cmejla, D Morais, P Baldrian (2019). High-throughput sequencing analysis of the bacterial community in stone fruit phloem tissues infected by "Candidatus Phytoplasma prunorum". Microb Ecol 77:664-675

FAO (2019). FAOSTAT [Online]. FAO. Available: http://www.fao.org/faostat/en/\#data/QC/visualize [Accessed $8 / 12 / 2019]$

Fierer N, M Bradford, R Jackson (2007). toward an ecological classificatin of soil bacterial. Ecology 88:1354-1364

Fließbach A, HR Oberholzer, L Gunst, P Mäder (2007). Soil organic matter and biological soil quality indicators after 21 years of organic and conventional farming. Agric Ecosyst Environ 118:273-284

Gans J, M Wolinsky, J Dunbar (2005). Microbiology: Computational improvements reveal great bacterial diversity and high toxicity in soil. Science 309:1387-1390

Gee GW, JW Bauder (1986). Particle size analysis. In: Methods of Soil Analysis, pp:383-411. Klute A (Ed.), Part I. Physical and mineralogical methods. American Society of Agronomy, Madison, Wisconsin, USA

Grantina L, K Kenigsvalde, D Eze, Z Petrina, I Skrabule, N Rostoks, V Nikolajeva (2011). Impact of six-year-long organic cropping on soil microorganisms and crop disease suppressiveness. Zemdirb Agric 98:399-408

He XY, YR Su, YM Liang, XB Chen, HH Zhu, KL Wang (2012). Land reclamation and short-term cultivation change soil microbial communities and bacterial metabolic profiles. J Sci Food Agric 92:1103-1111

Jangid K, MA Williams, AJ Franzluebbers, JS Sanderlin, JH Reeves, MB Jenkins, DM Endale, DC Coleman, WB Whitman (2008). Relative impacts of land-use, management intensity and fertilization upon soil microbial community structure in agricultural systems. Soil Biol Biochem 40:2843-2853 
Jenkins SN, IS Waite, A Blackburn, R Husband, SP Rushton, DC Manning, AG O'Donnell (2009). Actinobacterial community dynamics in long term managed grasslands. Anton Leeuwen 95:319-334

Jesus EDC, TL Marsh, JM Tiedje, FMDS Moreira (2009). Changes in land use alter the structure of bacterial communities in western amazon soils. ISME J 3:1004-1011

Jin X, J Wang, D Li, F Wu, X Zhou (2019). Rotations with indian mustard and wild rocket suppressed cucumber fusarium wilt disease and changed rhizosphere bacterial communities. Microorganisms 7; Article 57

Jones RT, MS Robeson, CL Lauber, M Hamady, R Knight, N Fierer (2009). A comprehensive survey of soil acidobacterial diversity using pyrosequencing and clone library analyses. ISME J 3:442-453

Kazeeroni EA, AM Al-Sadi (2016). 454-pyrosequencing reveals variable fungal diversity across farming systems. Front Plant Sci 7; Article 314

Krishna MP, M Mohan (2017). Litter decomposition in forest ecosystems: A review. Ener Ecol Environ 2:236-249

Lauber CL, MS Strickland, MA Bradford, N Fierer (2008). The influence of soil properties on the structure of bacterial and fungal communities across land-use types. Soil Biol Biochem 40:2407-2415

Lehtovirta-Morley LE (2018). Ammonia oxidation: Ecology, physiology, biochemistry and why they must all come together. FEMS Microbiol Lett 365; Article fny058

Li Y, L Chen, H Wen, T Zhou, T Zhang, X Gao (2014). 454 pyrosequencing analysis of bacterial diversity revealed by a comparative study of soils from mining subsidence and reclamation areas. J Microbiol Biotechnol 24:313-323

Ling N, C Zhu, C Xue, H Chen, Y Duan, C Peng, S Guo, Q Shen (2016). Insight into how organic amendments can shape the soil microbiome in long-term field experiments as revealed by network analysis. Soil Biol Biochem 99:137-149

Liu Z, C Lozupone, M Hamady, FD Bushman, R Knight (2007). Short pyrosequencing reads suffice for accurate microbial community analysis. Nucl Acids Res 35; Article e120

Meyer O (1994). Functional groups of microorganisms. In: Biodiversity and Ecosystem Function, pp:67-96. Schulze ED, HA Mooney (Eds.) Springer, Berlin, HeidelbergNacke H, A Thürmer, A Wollherr, C Will, L Hodac, N Herold, I Schöning, M Schrumpf, R Daniel (2011). Pyrosequencing-based assessment of bacterial community structure along different management types in German forest and grassland soils. PLoS One 6: Article e17000

Nunan N, H Schmidt, X Raynaud (2020). The ecology of heterogeneity: Soil bacterial communities and C dynamics. Phil Trans Roy Soc B Biol Sci 375:1-23

Pan Y, N Cassman, MD Hollander, LW Mendes, H Korevaar, RHEM Geerts, JAV Veen, EE Kuramae (2014). Impact of long-term N, P, $\mathrm{K}$, and NPK fertilization on the composition and potential functions of the bacterial community in grassland soil. FEMS Microbiol Ecol 90:195-205

Qin L, F Xu, Y Liu, X Wang, Q Li, X Yun (2018). Analysis of soil bacterial diversity under cucumber-celery intercropping and its influence on cucumber Fusarium wilt. Chin J Eco-Agric 26:1180-1189

Qu TB, WC Du, X Yuan, ZM Yang, DB Liu, DL Wang, L Yu (2016). Impacts of grazing intensity and plant community composition on soil bacterial community diversity in a steppe grassland. PLoS One 11; Article e0159680
Ramirez KS, CL Lauber, R Knight, MA Bradford, N Fierer (2010). Consistent effects of nitrogen fertilization on soil bacterial communities in contrasting systems. Ecology 91:3463-3470

Raza W, J Wang, A Jousset, VP Friman, X Mei, S Wang, Z Wei, Q Shen (2020). Bacterial community richness shifts the balance between volatile organic compound-mediated microbe-pathogen and microbe-plant interactions. Proc Biol Sci 287:1-33

Rousk J, PC Brookes, E Bååth (2009). Contrasting soil pH effects on fungal and bacterial growth suggest functional redundancy in carbon mineralization. Appl Environ Microbiol 75:1589-1596

Sandaa RA, V Torsvik, Ø Enger (2001). Influence of long-term heavymetal contamination on microbial communities in soil. Soil Biol Biochem 33:287-295

Smit E, P Leeflang, S Gommans, JVD Broek, SV Mil, K Wernars (2001). Diversity and seasonal fluctuations of the dominant members of the bacterial soil community in a wheat field as determined by cultivation and molecular methods. Appl Environ Microbiol 67:2284-2291

Soupir ML, S Mostaghimi, ER Yagow, C Hagedorn, DH Vaughan (2006). Transport of fecal bacteria from poultry litter and cattle manures applied to pastureland. Water Air Soil Pollut 169:125-136

Ventura M, C Canchaya, A Tauch, G Chandra, GF Fitzgerald, KF Chater, D Van Sinderen (2007). Genomics of actinobacteria: Tracing the evolutionary history of an ancient phylum. Microbiol Mol Biol Rev $71: 495-548$

Volossiouk T, EJ Robb, RN Nazar (1995). Direct DNA extraction for PCRmediated assays of soil organisms. Appl Environ Microbiol 61:3972 3976

Wang Z, J Zhang, F Wu, X Zhou (2018). Changes in rhizosphere microbial communities in potted cucumber seedlings treated with syringic acid. PLoS One 13; Article e 0200007

Wu T, DO Chellemi, JH Graham, KJ Martin, EN Rosskopf (2008) Comparison of soil bacterial communities under diverse agricultural land management and crop production practices. Microb Ecol 55:293-310

Xu J, Y Zhang, P Zhang, P Trivedi, N Riera, Y Wang, X Liu, G Fan, J Tang, HD Coletta-Filho, J Cubero, X Deng, V Ancona, Z Lu, B Zhong, MC Roper, N Capote, V Catara, G Pietersen, C Vernière, AM Al-Sadi, L Li, F Yang, X Xu, J Wang, H Yang, T Jin, N Wang (2018). The structure and function of the global citrus rhizosphere microbiome. Nat Commun 9; Article 4894

Xue L, H Ren, S Li, X Leng, X Yao (2017). Soil bacterial community structure and co-occurrence pattern during vegetation restoration in karst rocky desertification area. Front Microbiol 8; Article 2377

Yang W, H Yan, J Zhang, Y Meng, X Wang, L Ji, Y Luo (2017). Response of rhizosphere microbial diversity and soil physico-chemical properties in a rotation of cucumber with Volvariella volvacea. Biocontr Sci Technol 27:311-323

Zhang H, LL Schroder, JJ Pittman, JJ Wang, ME Payton (2005). Soil salinity using saturated paste and 1;1 soil and water extracts. Soil Sci Soc Amer J 69:1146-1151

Zhang X, J Halder, RP White, DJ Hughes, Z Ye, C Wang, R Xu, B Gan, BDL Fitt (2014). Climate change increases risk of fusarium ear blight on wheat in central China. Ann Appl Biol 164:384-395

Zhou J, X Jiang, D Wei, B Zhao, M Ma, S Chen, F Cao, D Shen, D Guan, J $\mathrm{Li}$ (2017). Consistent effects of nitrogen fertilization on soil bacterial communities in black soils for two crop seasons in China. Sci Rep 7; Article 3267 